\title{
TLC-Bioautography Profile of Ethyl Acetate Extract of 5 Bacteria Isolated from Ficus carica L Rhizosphere
}

\author{
Nanik Sulistyani, Iin Narwanti \\ Faculty of Pharmacy, Universitas Ahmad Dahlan, Yogyakarta, Indonesia
}

\begin{tabular}{|c|c|}
\hline Article Info & ABSTRACT \\
\hline Article history: & \multirow{9}{*}{$\begin{array}{l}\text { Research has been conducted on the } 5 \text { isolates of bacteria isolated from the } \\
\text { rhizosphere of Ficus carica L as a producer of antibiotics. The previous } \\
\text { study showed they have NRPS gene profiles that differ from each other. This } \\
\text { study aims to determine the TLC Rf spots having inhibition activity against } \\
\text { the growth of Staphylococcus aureus ATCC } 25923 \text { and Escherichia coli } \\
\text { ATCC } 25922 \text {. The study was conducted using the } 5 \text { bacteria isolates, namely } \\
\text { T19, T24, T25, T37 and T41. All isolates were fermented at room } \\
\text { temperature for } 14 \text { days. Further the each broth culture was filtered and } \\
\text { extracted using ethyl acetate. Components in the extract were separated by } \\
\text { thin layer chromatography (TLC) with the mobile phase of chloroform- } \\
\text { methanol (7: 3), followed by bioautography test against the } S \text {. aureus and } E \text {. } \\
\text { coli to determine the chromatogram spots containing antibiotics. TLC results } \\
\text { showed all isolates had different chromatogram profiles. The bioautography } \\
\text { results showed that only isolate T25 can produce antibiotics against } S \text {. } \\
\text { aureus. The antibiotic spot was at Rf } 0.9 \text { in the use of chloroform-methanol } \\
\text { (7: 3) solvent system. }\end{array}$} \\
\hline Received Dec 30, 2014 & \\
\hline Revised Feb 20, 2015 & \\
\hline Accepted Apr 26, 2015 & \\
\hline Keyword: & \\
\hline Antibiotics & \\
\hline Bioautography & \\
\hline E. coli & \\
\hline S. aureus & \\
\hline
\end{tabular}

Copyright () 2015 Institute of Advanced Engineering and Science. All rights reserved.

\section{Corresponding Author:}

Nanik Sulistyani, Faculty of Pharmacy, Universiats Ahmad Dahlan, Jalan Prof. Dr. Soepomo, S.H., Janturan, Warungboto, Umbulharjo 55612, Yogyakarta, Indonesia. Email: naniksulistyani@gmail.com

\section{INTRODUCTION}

The emergence of pathogenic microbial resistance to various antibiotics (multiresistant) is a serious problem in the treatment of infectious diseases. Multiresistant of microbial pathogens increases the morbidity and mortality due to infectious diseases. This multiresistant encourage researchers in the world to find new and more sensitive antibiotics against resistant microbial pathogens [1]-[3].

One potential source of new antibiotic molecules is Actinomycetes. Historically, Actinomycetes produce the largest number of classes of antibiotics such as tetracycline, aminoglycosides, cephalosporins and macrolides [4]. Actinomycetes is also a source of new antibiotics and compounds with various pharmacological activities guide [4],[5]. Ogunmwonyi et al. [6] stated that approximately $70 \%$ of antibiotics were found to originate from Actinomycetes, so Actinomycetes become a source of potential for exploration produce drugs, particularly new antibiotics [7].

Many screenings have been carried out and resulted in thousands of bioactive molecules from microbes. Therefore a new approach is needed to reduce the likelihood of rediscovery of known compounds [8]. Systematic approach or a new technology in the search for new drug candidate compounds [9]-[11] should be applied, so that the processes are carried out no vain. This approach can be done with the application of analysis to identify and eliminate secondary metabolites are already known in the research process as early as possible. This analysis is also called dereplication. 
Dereplication is a process for screening by comparing compounds or secondary metabolites that are already known to the alleged new compounds, so there is no repetition of research for the results or the same compound [12]. Dereplication can be applied to extract natural materials that contain certain compounds or metabolites [12], microbial (eg Actinomycetes) as well as genes that encode metabolites [13]. Various approaches have been carried out, among others dereplication in molecular, spectroscopy, or combinations thereof.

Molecular or genomic approaches show remarkable progress in recent years [14]-[19]. One approach is mostly done by analysis of the polyketide synthase (PKS) and non-ribosomal peptide syntetase (NRPS) genes [13],[20]-[21]. PKS and NRPS genes are the genes encoding polyketides and non-ribosomal peptides. Polyketides and non-ribosomal peptides are the collection of multifunctional proteins that synthesize secondary metabolites [22]. The difference in the profile of these genes showed a group of secondary metabolites produced differences.

Approach with spectroscopic analysis plays an important role in the process of the discovery of antibiotics. This analysis can be used early in the process to detect the presence of certain compounds in the extract. Several spectroscopic methods have been used to dereplication such as HPLC [23], NMR [12] and LC-MS [24]-[25].

Infrared radiation (IR) can potentially be used to dereplication. This is because two molecules of different compounds chemical structure will produce a different IR spectrum. This is due to the different bond types or different vibration frequencies. Although the same kinds of bonds, but different compounds, the different frequency because of the common bond being in a different environment [26]. In general, the molecules have many bonds and each bond can produce some kind of IR-active vibrations. IR spectra are complex and there are many absorption bands of overlapping and distinctive for each compound. Therefore the spectrum of IR spectra is used to identify compounds by comparing the IR spectra with reference compounds (finger printing) [27]. Until recently, IR spectroscopy has not been used for metabolite dereplication of Actinomycetes. Therefore the use of IR spectroscopy method is an application of the new method to do dereplication in antibiotic exploration. It is expected that this can be a standard method in the next period (finger printing) [29].

Previous studies [28]-[29] have successfully obtained 13 isolates of Actinomycetes which are expected to produce antibiotics. Based on RFLP analysis of the NRPS gene, they can be classified into 5 groups. Each group can be taken 1 isolate for further study, so there are 5 isolates to be further investigated. Hence this research is important to be continued so that the antibiotic can be characterized and expected to obtain new antibiotics.

\section{RESEARCH METHOD}

Materials: Starch Nitrate Agar/Broth, Nutrient Agar, Mueller Hinton Agar, Staphylococcus aureus ATCC25923, Escherichia coli ATCC25922, ethyl acetate, TLC plate. Procedure:

1. Fermentation

1 loop (loop) actinomycetes colonies was inoculated in $5 \mathrm{~mL}$ of medium Starch-Nitrate Broth and incubated on a rotary shaker at 200-250 rpm for 5 days at room temperature. The culture was then inoculated into $100 \mathrm{ml}$ Liquid Starch-Nitrate in $500 \mathrm{~mL}$ Erlenmeyer and incubated at room temperature shaker 14 days. Then the culture was transferred to a conical tube and centrifuged at $3000 \mathrm{rpm} 15$ minutes. The supernatant was taken as a source of secondary metabolites.

2. Extraction of secondary metabolites

The supernatant containing secondary metabolites was extracted with ethyl acetate (1: 1) (v/v) by shaking for 10 minutes. The top layer was taken with a Pasteur pipette inserted in the tube. Extraction was carried out 2 times. Ethyl acetate phase was collected and passed through a column of sodium sulfate that has been filled. Subsequently, the filtrate evaporated to a volume of $1 \mathrm{~mL}$ and stored in the refrigerator for the next test.

3. Thin Layer Chromatography (TLC)

TLC of ethyl acetate extracts was performed with the stationary phase of silica gel F254 (E. Merck) and mobile phase of chloroform-methanol (7: 3). Chromatogram detection is done by ultra violet rays 254 and $366 \mathrm{~nm}$

4. Preparation of test bacteria

1 ose bacterial colonies of $S$. aureus and E. coli were grown in $1 \mathrm{~mL}$ of BHI, and incubated for 24 hours at $37^{\circ} \mathrm{C}$. Subsequently, it was taken $100 \mathrm{uL}$ and put into $1 \mathrm{~mL}$ of BHI medium, incubated for 4 hours at $37^{\circ} \mathrm{C}$. Then it was diluted with $0.9 \% \mathrm{NaCl}$ to turbidity equal to the Mc Farland standard $\left(10^{8} \mathrm{CFU} / \mathrm{mL}\right)$. The test bacterial suspension was spread on Mueller Hinton medium. 
5. Bioautography

The bioautography against test bacteria of TLC plate containing patches chromatogram was carried out on Mueller Hinton agar medium. The examination was performed by touching the TLC plate for 30 minutes on Mueller Hinton agar medium were previously cultivated the bacteria test. Subsequently, it was incubated at $37^{\circ} \mathrm{C}$ for $18-24$ hours. The existence of sterile zone (no growth of bacterial colonies) after incubation reveals that the chromatogram spots contain antibiotic compounds

\section{RESULTS AND ANALYSIS}

This study used 5 selected isolates having different NRPS (Non Ribosomal Peptide Synthetase) gene profiles coded isolate T19, T24, T25, T37 and T43. The fermentation process is carried out on each isolates at room temperature for 14 days. A total of $10 \mathrm{~mL}$ starter was cultured for 5 days at room temperature with agitation in $100 \mathrm{~mL}$ of SNB (Starch Nitrate Broth) medium. After 5 days, the starter was transferred into $1 \mathrm{~L}$ SNB medium and the incubation was continued for 5 days. A total of $300 \mathrm{ml}$ of culture, was then incubated in $3 \mathrm{~L}$ SNB medium for 14 days.

The culture was then filtered and extracted with ethyl acetate. The use of ethyl acetate has been widely applied in various research of antibiotics isolation. This is because antibiotics are generally semipolar and easily isolated with ethyl acetate [21],[30]. The product of extraction was then evaporated with rotaevaporator and obtained extracts. The extract was then performed TLC-bioautography. TLC is done with the stationary phase of silica gel F254 and the mobile phase of chloroform methanol (7: 3). TLC results are presented in Figure 1.
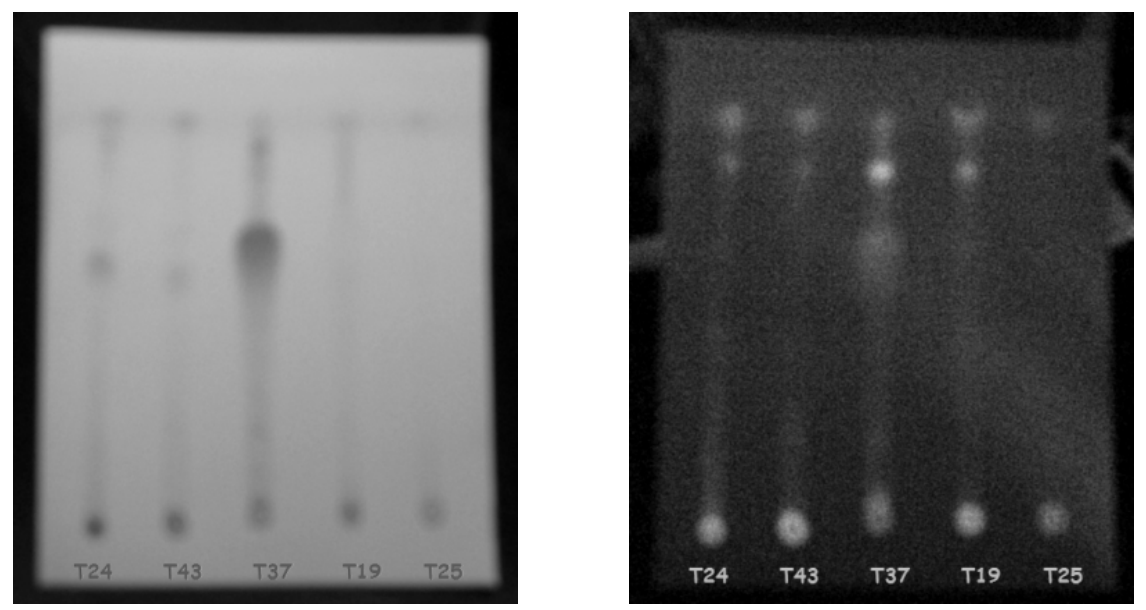

Figure 1. The TLC chromatograms under UV 254 nm (left) and UV 366 nm (right)

The Rf values as results of TLC to $1.25 \mathrm{mg}$ of ethyl acetate extracts of liquid cultures of each isolate can be calculated for each spot and are summarized in Table 1. 
Table 1. Rf Values of TLC chromatograms

\begin{tabular}{ccc}
\hline isolate & Rf (uv254) & Rf (uv366) \\
\hline T24 & 0 & 0 \\
& 0.15 & 0.28 \\
& 0.56 & 0.43 \\
& 0.84 & 0.84 \\
& 0.91 & 0.91 \\
T43 & 0 & 0 \\
& 0.19 & 0.19 \\
& 0.54 & 0.80 \\
T37 & 0.91 & 0.91 \\
& 0 & 0 \\
& 0.21 & 0.21 \\
& 0.70 & 0.70 \\
& 0.83 & 0.82 \\
T19 & 0.89 & 0.89 \\
& 0.93 & 0 \\
& 0 & 0.63 \\
& 0.25 & 0.82 \\
T25 & 0.76 & 0.93 \\
& 0.79 & 0 \\
& 0.91 & 0.91 \\
\hline
\end{tabular}

Based on Rf values of TLC spots (Table 1), it can be observed the diversity of isolates tested. There are 2 spots in T25, 3 spots in T43, 5 spots in T19 and T24, while T37 had 6 spots. Although T19 and T24 have the same number of spots, but the Rf value respective different. It indicated that the spots appeared in all isolates vary both the number of spots and their Rf values. This is consistent with the results of previous studies based on NRPS gene profile that shows the difference between all isolates tested [28]. The result of the analysis of the scatter plot between the number of patches and Rf values as listed in Figure 2 (UV detection at $254 \mathrm{~nm}$ ) and Figure 3 (UV detection at $366 \mathrm{~nm}$ ), indicated that the T25 is the most different isolate. T25 only showed 2 spots, but the others has more than 2 spots.

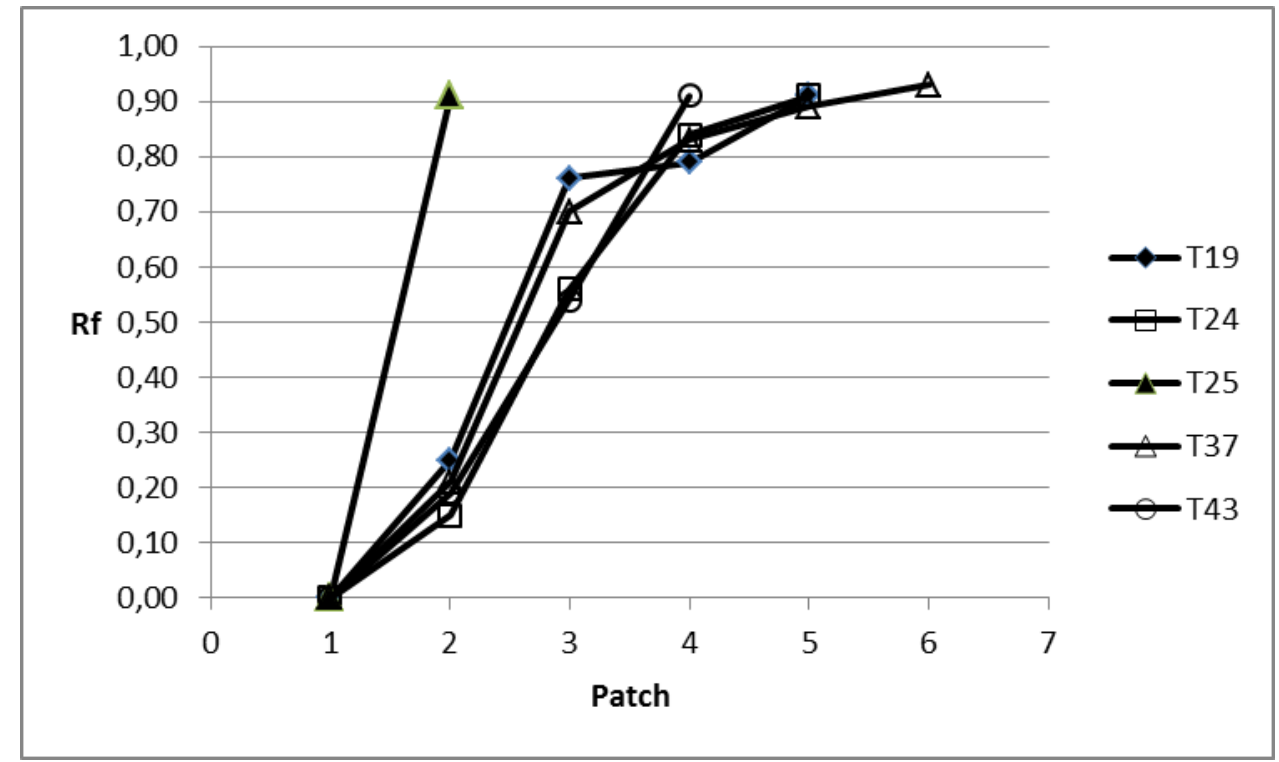

Figure 2. Scatter plot of the number of spots and Rf values at detection under UV light of $254 \mathrm{~nm}$ 


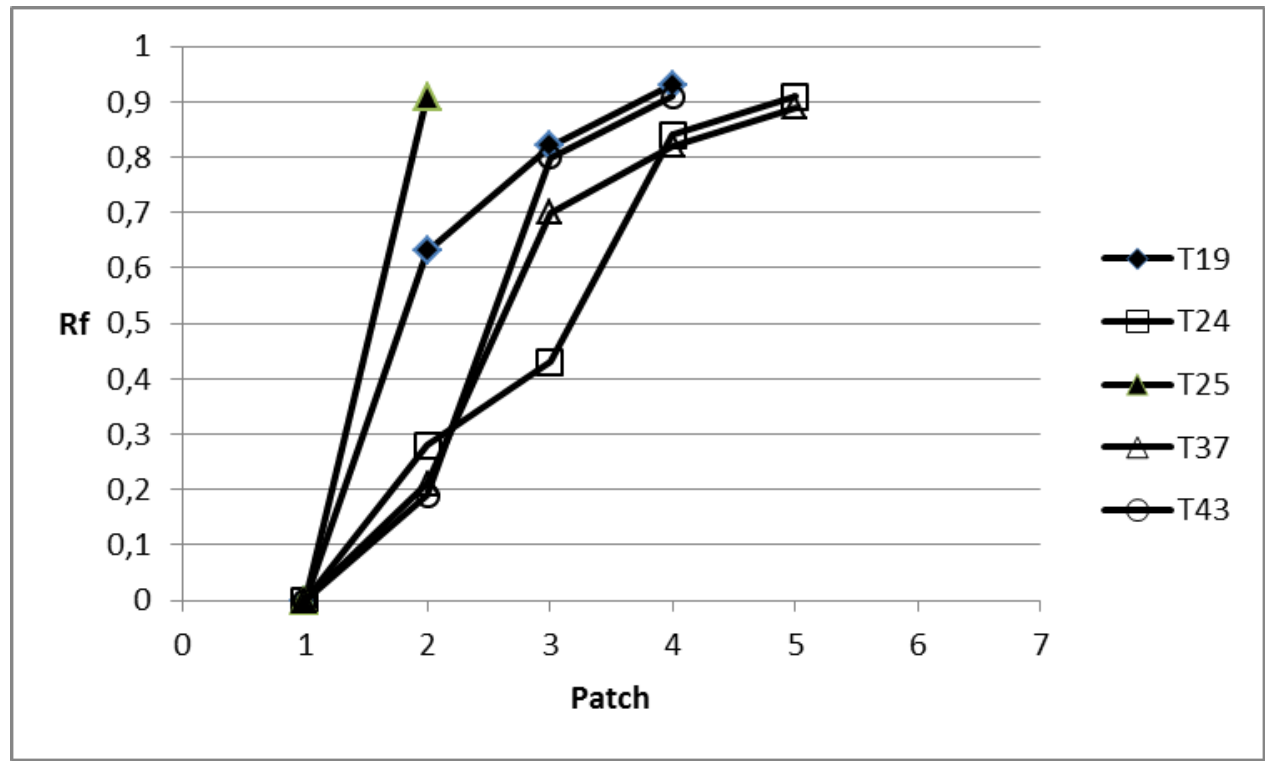

Figure 3. Scatter plot of the number of spots and Rf values at detection under UV light of $366 \mathrm{~nm}$

All of the TLC profiles showed that each extract contain only less than 5 spots and separated clearly. It also occurred in many of microbial metabolite [31], [32]. Therefore, it makes easy to purify the component of interest. Generally, TLC is used to do early separation. However, it also can be used to get purified compounds if the spot have been determined as the pure compounds.

The test results bioautography ethyl acetate extracts of liquid cultures of each isolate presented in Figure 4.

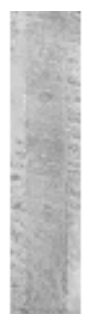

T19

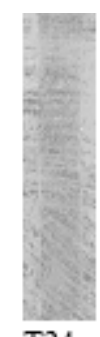

$\mathrm{T} 24$

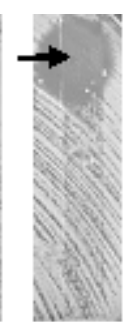

$\mathrm{T} 25$

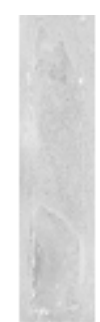

T37

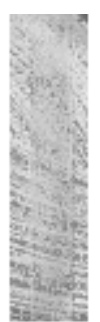

T43

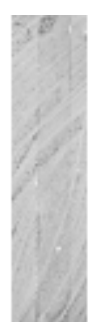

T19

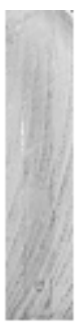

$\mathrm{T} 24$

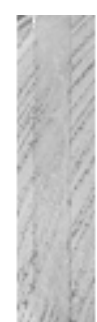

$\mathrm{T} 25$

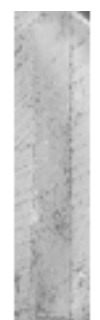

T37

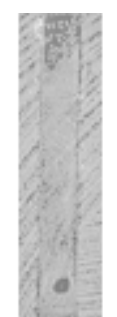

T43

Figure 4 Bioautography test results against $S$. aureus (left) and E. coli (right). The arrow shows the clear zone and indicates the inhibition of $S$. aureus growth by the compound in the active TLC-spot

The bioautography on TLC showed one clear zone only from the ethyl acetate extract of T25 against S. aureus. The clear zone appeared at Rf 0.91 in the solvent system of chloroform-methanol (7: 3). Therefore, it reveals that the spot contains antibiotic that can inhibit the $S$. aureus growth. The inhibition zone appears because the antibiotic can diffuse into the medium and inhibit the growth of $S$. aureus. Some of $S$. aureus were dead and showed the clear area on the medium that was previously spreaded by the examination bacteria [33]. Actually, the other isolates also had spot at around 0.91, but there was no inhibition zone over there. It indicated that the compound in the spot are different although the Rf value is same. Based on the Rf value of the active spot and the solvent system used in this study, it can be concluded that the active compound is a non polar. The non polar compound will be eluted faster then the polar in the chloroformmethanol (7: 3) solvent system.

Based on the bioautography results of T25, the antibiotic in T25 has narrow spectrum activity because the spot only inhibits the growth of $S$. aureus and didn't inhibit the growth of E. coli. S. aureus is a Gram positive bacteria, while E. coli is Gram negative.Thus, perhaps the antibiotic only suitable to kill the Gram positive bacteria, but not to Gram negative. In applications, usage of narrow spectrum antibiotic is better then the broad, because only certain bacteria will be killed. The limitation of this research is only use 2 kinds of bacteria (S. aureus and E. coli.). Actually there are still many kinds of other Gram positive and 
negative bacteria. So it is very important to perform it in the next experiment. Nevertheless, this result is very interesting and important to be continued in the subsequent purification process to get the pure antibiotic of interest from T25.

\section{CONCLUSION}

TLC results showed that all bacteria isolates had chromatogram profiles that differ each other. The bioautography results showed that only T25 isolate can produce antibiotics against $S$. aureus. The spot appeared at Rf 0.9 in the solvent system of chloroform-methanol (7: 3).

\section{REFERENCES}

[1] Oskay M., Tamer AU., Azeri C., "Antibacterial activity of some Actinomycetes isolated from farming soil of Turkey”, Afr J Biotechnol, vol/issue: 3(9), pp. 441-446, 2004.

[2] Parungao MM., Maceda EBG., Villano MAF., "Screening of Antibiotic-Producing Actinomycetes from Marine, Brackish and Terrestrial Sediments of Samal Island, Philippines”, Journal of Research in Science, Computing, and Engineering, vol/issue: 4(3), pp. 29-38, 2007.

[3] Sulistyani N., Muhlis M., Kustanti ND., Erinto E., Aquina H., Zainab, "Studi Resistensi Staphylococcus aureus Yang Diisolasi Dari Limbah Cair Beberapa Rumah Sakit Terhadap Antibotika”, Prosiding Seminar Nasional Kesehatan Lingkungan Untuk Mewujudkan Sehat Jasmani Rohani Bagi Anak Bangsa, 6 Januari 2009, Fakultas Kesehatan Masyarakat UAD,Yogyakarta, 2009.

[4] Berdy J., "Bioactive microbial metabolites. A personal view”, J Antibiot, vol/issue: 58(1), pp. 1-26, 2005.

[5] Singh SB., Genilloud O., Pela'ez F., "NP structural diversity II-secondary metabolite sources, evolution and selected molecular structures: terrestrial micro-organisms_-bacteria”, In: Mander L, Liu H-W (eds) Comprehensive natural products II. Chemistry and biology. Elsevier, UK, 2010.

[6] Ogunmwonyi IH., Mazomba N., Mabinya L., Ngwenya E., Green E., Akinpelu DA., Olaniran AO., Bernard K., Okoh AI., "Studies on the culturable marine actinomycetes isolated from the Nahoon beach in the Eastern Cape Province of South Africa”, Afr. J. Microbiol. Res., pp. 2223-2230, 2010.

[7] Genilloud O., Gonzalez I., Salazar O., Jesus Martın J., Tormo JR., Vicente F., "Current approaches to exploit actinomycetes as a source of novel natural products”, J Ind Microbiol Biotechnol, 2010. DOI 10.1007/s10295-0100882-7.

[8] Busti E., Monciardini P., Cavaletti L., Bamonte R., Lazzarini A., Sosio M., Donadio S., “Antibiotic-producing ability by representatives of a newly discovered lineage of actinomycetes”, Microbiology, vol. 152, pp. 675-683, 2006.

[9] Baltz RH., "Renaissance in antibacterial discovery from actinomycetes”, Curr Opin Pharmacol, vol. 8, pp. 557563, 2008.

[10] Clardy J., Fischbach MA., Walsh CT., “New antibiotics from bacterial natural products”, Nat. Biotechnol, vol. 24, pp. 1541-1550, 2006.

[11] Newman DJ., Cragg GM., "Natural products as sources of new drugs over the last 25 years”, J Nat Prod, vol. 70, pp. 461-477, 2007.

[12] Lang G., Mayhudin NA., Maya I., Mitova MI., Sun L., Sun L., van der Sar S., Blunt JW., Cole AJL., Ellis G., Laatsch H., Munro MHG., "Evolving trends in the dereplication of natural product extracts: new methodology for rapid, small-scale investigation of natural product extracts”, J Nat Prod, vol. 71, pp. 1595-1599, 2008.

[13] Ayuso A., Clark D., Gonzalez I., Salazar O., Anderson A., Genilloud O., "A novel Actinomycetes strain dereplication approach based on the diversity of polyketide synthase and nonribosomal peptide synthetase biosynthetic pathways”, App Microbiol Biotechnol, vol. 67, pp. 795-806, 2005.

[14] Banik JJ., Brady SF., "Cloning and characterization of new glycopeptides gene clusters found in an environmental DNA megalibrary”, Proc Natl Acad Sci, vol. 105, pp. 17273-17277, 2008.

[15] Brady SF., Simmons L., Kim JH., Schmidt EW., "Metagenomic approaches to natural products from free-living and symbiotic organisms”, Nat Prod Rep, vol. 26, pp. 1488-1503, 2009.

[16] Corre C., Challis GL., "New natural product biosynthetic chemistry discovered by genome mining”, Nat Prod Rep, vol. 26, pp. 977-986, 2009.

[17] Craig JW., Chang FY., Brady SF., "Natural products from environmental DNA hosted in Ralstonia metallidurans”, ACS Chem Biol, vol. 4, pp. 23-28, 2009.

[18] Nett M., Ikeda H., Moore BS., “Genomic basis for natural product biosynthetic diversity in the actinomycetes”, Nat Prod Rep, vol. 26, pp. 1362-1384, 2009.

[19] Scherlach K, Hertweck C., “Triggering cryptic natural product biosynthesis in microorganisms”, Org Biomol Chem, vol. 7, pp. 1753-1760, 2009.

[20] Ayudo-Sacido A., Genilloud O., "New PCR primers for the screening of NRPS and PKS - I systems in actinomycetes: detection and distribution of these byosynthetic gene sequences in major taxonomic groups", Microb. Ecol., vol. 49, pp. 10- 24, 2005.

[21] Farida Y., Widada J., Meiyanto E., "Combination Methods for Screening Marine Actinomycetes Producing Potential Compounds as Anticancer”, Indonesian Journal of Biotechnology, vol/issue: 12(2), pp. 988-997, 2007. 
[22] Radjasa OK., Wiese J., Sabdono A., Imhoff JF., "Corals As Source Of Bacteria With Antimicrobial Activity”, Journal of Coastal Development, vol/issue: 11(3), pp. 121-130, 2008.

[23] Tormo JR., Garcia JB., DeAntonio M., Feliz J., Mira A., Diez MT., Hernandez P., Pelaez F., "A method for the selection of production media for actinomycete strains based on their metabolite HPLC profiles”, $J$ Ind Microbiol Biotechnol, vol. 30, pp. 582-588, 2003.

[24] Cremen PA., Zeng L., "High-throughput analysis of natural product compound libraries by parallel LC-MS evaporative lightscattering detection”, Anal Chem, vol. 74, pp. 5492-5500, 2002.

[25] Genilloud O., Gonzalez I., Salazar O., Jesus Martın J., Tormo JR., Vicente F., "Current approaches to exploit actinomycetes as a source of novel natural products”, J Ind Microbiol Biotechnol, 2010. DOI 10.1007/s10295-0100882-7.

[26] Silverstein RM., Bassler GC., Morril TC., "Penyidikan Spektrometrik Senyawa Organik”, penterjemah Hartono AJ, Purba AV, Edisi IV, Erlangga, Jakarta, 1986.

[27] Field LD., Sternhell S., Kalman JR., “Organic Structures from Spectra”, Fourth Edition, John Wiley \& Sons Ltd, The Atrium, Southern Gate, Chichester,West Sussex PO19 8SQ, England, 2008.

[28] Sulistyani N., "Pendekatan Analisis Gen PKS I, NRPS dan LC-MS untuk mendapatkan Antibiotik Baru dari Actinomycetes”, Laporan Penelitian Fundamental, Fak Farmasi Univ Ahmad Dahlan, Yogyakarta, 2012.

[29] Sulistyani N., "Keragaman Isolat Actinomycetes Berdasarkan Analisis RFLP Terhadap Gen NRPS”, Farmaqiana, Jurnal Ilmiah Kefarmasian, vol/issue: 3(1), 2013.

[30] Riyanti, Widada J., Radjasa OK., "Isolation and Screening of Antimicrobial Producing-Actinomycetes Symbionts in Nudibranch”, Indonesian Journal of Biotechnology, vol/issue: 14(1), pp. 1132-1138, 2009.

[31] Sutherland TD., Weir KM., Lacey MJ., Horne I., Russell RJ., Oakeshott JG., "Enrichment of a microbial culture capable of degrading endosulphate, the toxic metabolite of endosulfan”, Journal of Applied Microbiology, vol. 92,

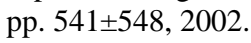

[32] Rante H., Wahyono, Murti YB., Alam G., "Purifikasi dan karakterisasi senyawa antibakteri dari actinomycetes asosiasi spons terhadap bakteri patogen resisten”, Majalah Farmasi Indonesia, vol/issue: 21(3), pp. 158 - 165, 2010.

[33] Pratiwi ST., “Mikrobiologi Farmasi”, Erlangga, Jakarta, 2008. 